\title{
Investigation of Oak Wood Biochar Gasification in Downdraft Gasifier Using Aspen Plus Simulation
}

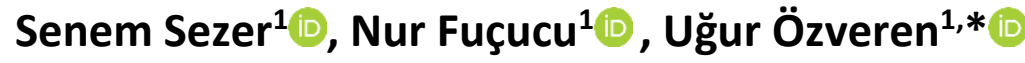 \\ ${ }^{1}$ Marmara University, Faculty of Engineering, Department of Chemical Engineering, 34730, Göztepe, İstanbul, Turkey
}

\section{Article History}

Received 18 June 2021

Accepted 27 September 2021

First Online 15 November 2021

\section{Corresponding Author}

Tel.: +9002167773698/3698

E-mail:

ugur.ozveren@marmara.edu.tr

\section{Keywords}

Biochar

Oak Wood

Gasification

Downdraft Gasifier

Aspen Plus ${ }^{\circledast}$

\begin{abstract}
In response to increasing energy demands and the inevitable release of greenhouse gases into the environment, researchers have turned their attention to biomass energy production. Biomass offers a lot of benefits; however, it has poor calorific value due to its higher moisture and volatile content. Carbonization can be used to overcome this disadvantage and produce biomass with a higher carbon content. One of the most promising thermochemical conversion techniques is gasification. In this study, biochar from oak wood was gasified in a steam environment using Aspen Plus ${ }^{\circledR}$ simulation. The downdraft gasifier model was developed under steady-state equilibrium parameters based on the minimization of Gibbs free energy. As consistent with the literature, $\mathrm{H}_{2}$ was produced higher amount in the steam gasification (55.65\%) compared with the air gasification (17.36\%). Parametric analyzes were performed to investigate the influence of the operating parameters on the composition of the syngas. Results depicted that the increasing temperature and steam/biochar ratio raised the $\mathrm{H}_{2}$ concentration from $53.21 \%$ to $55.72 \%$ and $54.50 \%$ to $56.84 \%$ in syngas respectively. Temperature also showed positive influence on the LHV of syngas that changed between 19620-19708 $\mathrm{kJ} / \mathrm{kg}$. The steam $/$ biochar ratio affected the LHV of syngas negatively thus it decreased from 20257 to $18777 \mathrm{~kJ} / \mathrm{kg}$.
\end{abstract}

\section{Introduction}

Fossil fuels are one of the main energy sources that still account for about $90 \%$ of the energy used worldwide (Cao et al., 2020). Transportation, heating and many industires obtain energy through the conversion of energy derived from fossil fuels in various forms. There is a growing concern about the risk of fossil fuel extinction and emissions of detrimental gases from excessive fossil fuel use that causes ecological depletion and health problems (Cao et al., 2020). This concern is leading to an increasing demand to meet today's energy supply from renewable energy sources.

Renewable energy resources do not harm nature due to the ecological occurrence of them. However, renewable sources provides less energy than fossil fuels.
Wind, solar, and biomass are the most popular and widely used renewable energy sources nowadays. Among these, biomass has the status of one of the most used resources due to its naturally higher energy content and widespread availability (Safarian et al., 2020). Today, the use of biomass among the renewable energy sources is around $14 \%$ (Menon et al., 2021). It has been found that $90 \%$ of renewable energy consumption can be derived from biomass in rural areas of developing countries (Menon et al., 2021). Therefore, it is expected that in the coming years, the importance of biomass and development of the systems for utilization of biomass will increase remarkably. Thermochemical conversion reduces the inherent disadvantages of solid biomass such as processing, storage and low energy density (Rabea et al., 2021). It is 
well known that the most efficient thermochemical method for converting biomass into energy is gasification. Gasification is a technology that has been known for many years, mostly converts solid fuels into gaseous fuels for various applications (Beagle et al., 2018). Due to the physicochemical structure of biomass, fixed bed downdraft gasifier is the most commonly used gasifier type (Susastriawan \& Saptoadi, 2017). In downdraft gasifiers, the biomass fed from above passes through the drying, pyrolysis, oxidation or reduction zone and the syngas is produced from bottom (Susastriawan \& Saptoadi, 2017). Combustible syngas is a mixture of oxygen $\left(\mathrm{O}_{2}\right)$, nitrogen $\left(\mathrm{N}_{2}\right)$ and ash residues with carbon dioxide $\left(\mathrm{CO}_{2}\right)$ as well as methane $\left(\mathrm{CH}_{4}\right)$, carbon monoxide (CO), hydrogen $\left(\mathrm{H}_{2}\right)$ and small amounts of light hydrocarbons (Karatas et al., 2013). The concentrations of these components in the syngas determine the effectiveness and quality of the whole conversion process (Rabea et al., 2021). The most important parameters for evaluating biomass gasification performance are the cold gas yield, lower calorific value and the volume of syngas per unit weight of biomass (Guo et al., 2014). The properties of the syngas mainly depend on the design of the gasifier, selected gasifying agent and the gasification conditions. In addition, biomass content, particle size, and moisture content are the parameters that affect the syngas concentration and quality. Steam as gasfying agent allows to produce higher $\mathrm{H}_{2}$ and energy content syngas compared to others (air or pure $\mathrm{O}_{2}$ ) (Hosseini et al., 2012; Udomsirichakorn \& Salam, 2014).

Biomass gasification releases much less carbon emissions compared with the coal gasification (Ding et al., 2014). In addition, biomass as fuel offers many advantages in the gasification process in terms of lower ash and sulfur content. Direct use of biomass as fuel significantly reduces gasification efficiency due to its high moisture and volatile contents (Beagle et al., 2018). Feedstocks with high moisture content dry by absorbing the heat generated as a result of exothermic reactions during gasification. However, as a biomass absorbs the heat required for the endothermic reactions taking place, they cause a significant reduction in the efficiency of these reactions (Sharma et al., 2021). To prevent this, biomass is dried before use and the moisture and volatile contents are highly removed. Furthermore, when biomass is converted into biochar, heat treatment converts unstable carbons into stable ones and largely prevents the release of $\mathrm{CO}_{2}$ into the atmosphere through decomposition (Spokas, 2010).

In order to proceed the gasification reaction as efficiently as possible and produce the richest synthesis gas, the gasification conditions and fuel properties should be investigated many times to find the optimum condition. Experimental works, even in a laboratory scale gasifier system, take quite a long time and waste energy. Simulation models are very good at predicting process performance and providing descriptions of both the chemical and physical processes in the gasifier
(Baruah \& Baruah, 2014). It is also possible to provide an assessment of plant performance by optimizing the design and operating of the gasifier with minimal time and cost.

Aspen Plus is one of the simulators widely used in thermochemical process modeling, offering flexible operating conditions and providing reliable results (Doherty et al., 2013; Fernandez-Lopez et al., 2017). Aspen Plus has a rich library of equipment for chemical engineering research, such as reactors, columns, heat exchangers, pumps, valves, and compressors. A detailed flow diagram can be easily created by showing material, energy and work flows. It has an extensive database of flow properties required to describe solid, liquid and vapor phase flows. Aspen Plus can model drying, pyrolysis, evaporation, combustion and gasification processes successfully (Patra \& Sheth, 2015). In addition, sensitivity analyzes can be performed within the Aspen Plus ${ }^{\circledR}$ software and the model created can be optimized according to the desired parameters.

In this study, oak wood biochar, which has a high waste potential in Turkey, was selected as a fuel for gasification process. A model that minimizes Gibbs free energy was designed using Aspen Plus $^{\circledR}$ simulation software to optimize the reaction conditions and system design. A sensitivity analysis for the gasifier temperature and steam/biochar ratio was performed to optimize the process performance. The results obtained as a result of the sensitivity analysis showed a similar trend that reported in the literature.

\section{Materials and Methods}

\section{Sample}

In this study, oak wood biochar taken from the literature was used as fuel sample during the modeling of the fixed bed downdraft gasifier in Aspen Plus (Beagle et al., 2018). The high amount of lignin in the structure of the oak wood and its dense and hard texture made the oak wood as a preferable fuel in the scope of this study. Biochar and bio-oil are produced by the heat treatment of biomass. This process also named as high temperature pyrolysis. This treatment process deteriorates the tight fibrous structure of oak wood and it provides higher calorific value, lower moisture content. Due to these advantages of the conversion of biomass into biochar, syngas can be produced with higher yield and quality. Proximate and ultimate analysis results of oak wood biochar used in this study are given in Table 1.

\section{Modeling of Downdraft Gasifier}

In this study, Aspen PLUS $^{\oplus}$ V11 simulation program, a product of Aspen Technology, was used to model of fixed bed downdraft gasifier system. The downdraft gasifier model was developed based on minimization of the Gibbs free energy approach under steady-state 
Table 1. Proximate and ultimate analysis results of oak wood biochar (Beagle et al., 2018)

\begin{tabular}{cc}
\hline Proximate Analysis (As Received) & Oak Wood Biochar \\
\hline Moisture & $<0.01$ \\
Ash & 3.49 \\
Volatile Matter & 17.6 \\
Fixed Carbon & 78.9 \\
\hline Ultimate Analysis (Dry) & \\
\hline Carbon & 84.1 \\
Hydrogen & 3.41 \\
Nitrogen & 0.14 \\
Sulfur & 0.02 \\
Oxygen & 8.86 \\
Ash & 3.49 \\
\hline
\end{tabular}

conditions in Aspen PLUS ${ }^{\oplus}$ simulation program. The Gibbs free energy minimization approach is a common technique that used to examine the performance of gasification processes. Soave-Redlich-Kwong (SRK) as equation of state was chosen to conduct thermodynamic calculations.

Some assumptions were applied during development process of the Aspen PLUS ${ }^{\oplus}$ simulation model as follows:

$\checkmark$ Gasification process is isothermal and steady state.

$\checkmark$ Bio-char conversion is $100 \%$ during gasification.

$\checkmark$ All reactions take place rapidly and reach chemical equilibrium.

$\checkmark$ Biochar thermolysis products are mainly consist of $\mathrm{CO}_{2}, \mathrm{H}_{2}, \mathrm{CH}_{4}, \mathrm{CO}$ and $\mathrm{H}_{2} \mathrm{O}$.

$\checkmark$ Tar and other heavy hydrocarbons are neglected.

$\checkmark \quad$ Ash is considered inert and does not participate in reactions.

The model of the fixed bed downdraft gasifier which adopted from previous study in the literature was presented in Figure 1 (Sezer et al., 2021).

The oak wood biochar as non-conventional component was introduced to the system with its proximate and ultimate analysis results. Before the biochar is fed into the system, it was sent to the "PYRO" block to turn its nonconventional structure into conventional. While developing the model, three basic gasification steps were taken into consideration and simulated. These are pyrolysis, reduction and oxidation as named "ZONE1", "ZONE2" and "ZONE3" respectively. The Gibbs reactors were used for the simulation of these sections in the gasifier model. These three steps are not completely isolated from each other. Therefore fuel and gasification agent was sent to each part, but in different proportions. The "STEAM" flow, which is the gasification agent, was fed to "ST-SPLIT" divider block, and the "OAK" flow, which is the fuel, is sent to the "FEEDSPLT" divider block. Thus, the amount of fuel and gasifier agent in gasifier zones were adjusted using the splitter blocks. Then, the gas products obtained from the pyrolysis, gasification, and combustion zones were mixed in the "MIX" block. In the "WATSEP" block, the product gas was separated from any components that are not desired to be in the syngas like water and inert gas. The main goal of using combination of these blocks and reactors that the develoed downdraft gasifier model can work in harmony with real-life systems.

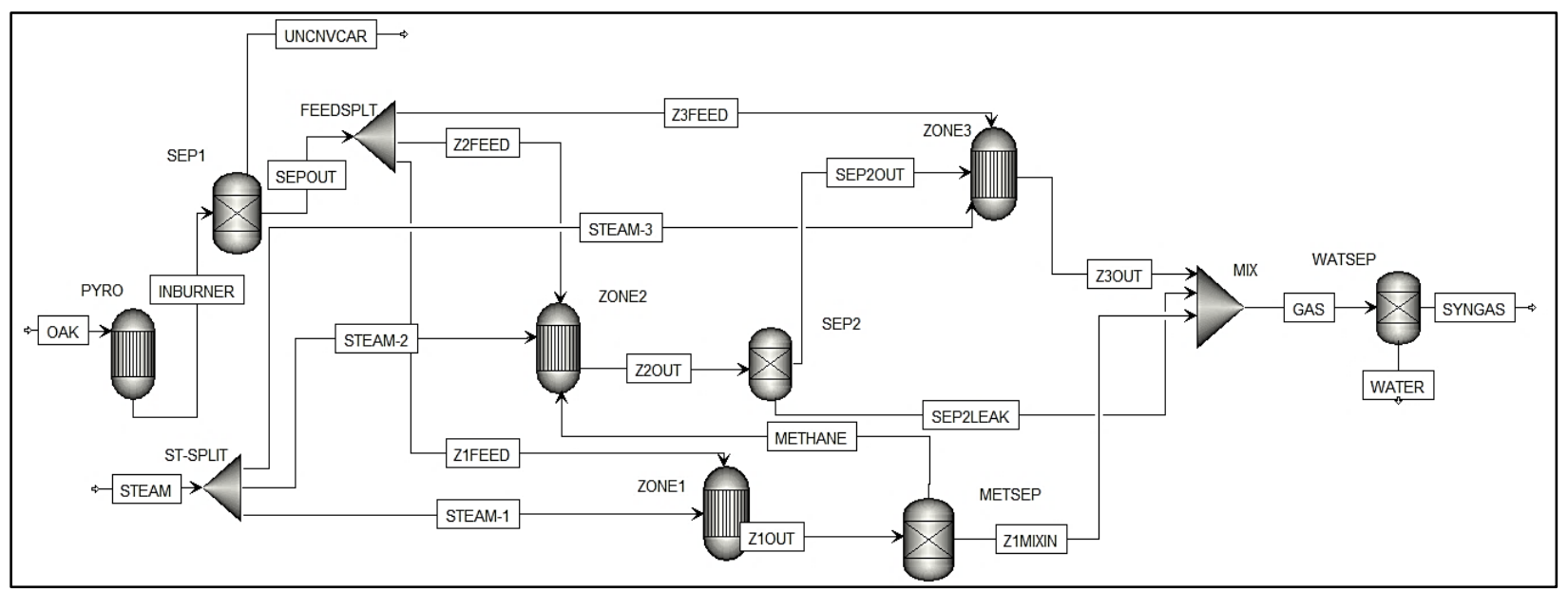

Figure 1. Flow diagram of the downdraft gasifier model in Aspen PLUS ${ }^{\circledR}$ simulation program (Sezer et al., 2021). 


\section{Results and Discussion}

The model development of downdraft gasifier using by Aspen PLUS ${ }^{\circ}$ simulation program was validated according to a study taken from the literature. After model validation, the composition of syngas obtained from gasification of oak wood biochar in the steam atmosphere was compared with syngas composition produced in the air atmosphere. The parametric study was conducted for the gasification of oak wood biochar in the steam atmosphere to investigate the influence of the gasifier temperature and steam/biochar ratio on the syngas composition and lower heating value (LHV) of syngas.

\section{Model Validation}

Downdraft gasifier model has been validated with an experimental and a simulation model from the literature in order to prove the accuracy of the developed model. The study from the literature focuses on biomass gasification in a fixed bed gasifier that simulated using Aspen PLUS ${ }^{\circ}$ simulation program. Experimental and simulation data of biomass gasification were defined identically to the model. The gasification conditions were $800^{\circ} \mathrm{C}$ and $1 \mathrm{~atm}$ and air was preferred as gasifiying agent. Softwood pellets was used as feedstock with $31.6 \mathrm{~kg} / \mathrm{h}$ flow rate, equivalent ratio (ER) was determined 0.2 and air flow rate was $35.244 \mathrm{Nm}^{3} / \mathrm{h}$ (Singh \& Tirkey, 2021). The syngas composition obtained by the model developed in this study under the same conditions with the experimental and simulation studies and their comparison results were given in Figure 2 .

When the gas compositions obtained at the end of the validation were examined, it was seen that the literature results were found very close to the results obtained from the designed model. The designed model gave better results than the literature simulation that compared with the experimental work in the same study. Even though the model was developed based on some assumptions such as reactions reach thermodynamic equilibrium, gas concentrations especially for $\mathrm{CH}_{4}$ and $\mathrm{N}_{2}$ proved that the model works appropriately with the real gasifier model.

\section{Comparison of Steam and Air Atmosphere in Gasification}

One of the main factors affecting the syngas composition is the gasification agent. In the literature, there are many gasification studies carried out in the steam or air atmosphere (Han et al., 2017; Paviet et al., 2009; Ramzan et al., 2011). Therefore, the choice of gasifying agent is very important to obtain syngas with desired composition. The simulation model was run under same operating conditions only by changing the gasifying agent to compare effect of gasifying agent as air and steam on the syngas composition. The comparison results of syngas compositions from air and steam gasifications in fixed bed downdraft gasifier were presented in Figure 3.

The major difference in the syngas composition under steam and air atmosphere occurred in the concentration of $\mathrm{N}_{2}$ and $\mathrm{H}_{2}$. The point to be considered here is the $\mathrm{H}_{2}$ concentration, because $\mathrm{H}_{2}$ can be used for many purposes in industry. The produced $\mathrm{H}_{2}$ was also examined in terms of molar flow rate alongside the mole fraction. When the steam was preferred as the gasifying agent $0.349 \mathrm{kmol} / \mathrm{h} \mathrm{H}_{2}$ was produced however only $0.097 \mathrm{kmol} / \mathrm{h} \mathrm{H}_{2}$ was obtained in the air atmosphere. The substantial difference in $\mathrm{H}_{2}$ molar flow rate was seen under same operating conditions and fuel feeding

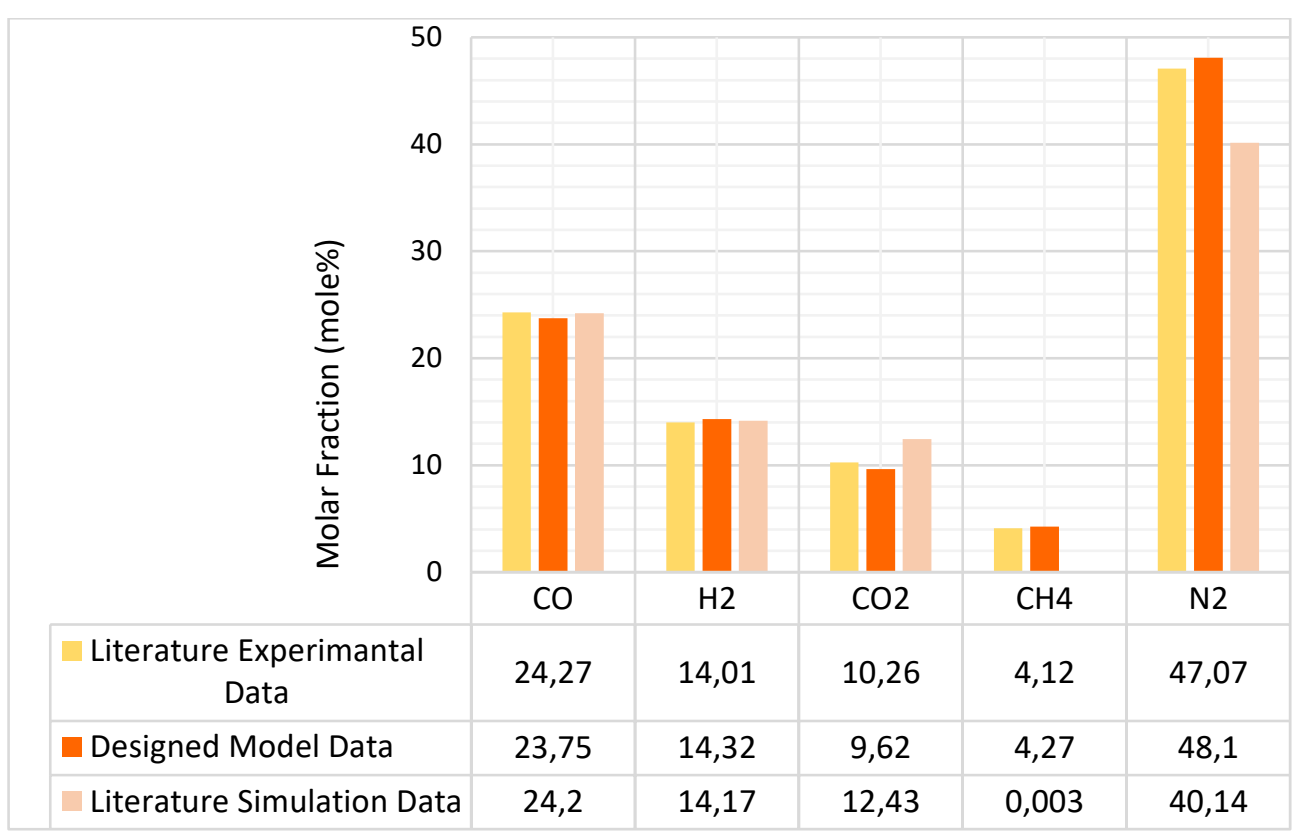

Figure 2. Comparison of syngas composition of designed model data and literature data 
$(10 \mathrm{~kg} / \mathrm{h})$. The studies in the literature support that the steam atmosphere is more advantageous for $\mathrm{H}_{2}$ production. It was concluded that $\mathrm{H}_{2}$ production is approximately four times more higher in the steam atmosphere compared with the air as same with literature (Rupesh et al., 2016).

\section{Sensitivity Analysis for Syngas Composition And LHV}

Gasifier temperature and steam/biochar ratio are the main parameters that are effective on the syngas composition and quality. Sensitivity analysis was performed to analyze the optimum syngas composition and LHV at varying gasifier temperature and steam/biochar ratio.

\section{Effect of Gasifier Temperature}

There are many reactions that take place during the gasification of biomass. The product quantity and quality of endothermic and exothermic reactions are greatly affected by the temperature increase and decrease due to changing of the equilibrium point. The operating temperature of the fixed bed downdraft gasifier model was varied between $600-900^{\circ} \mathrm{C}$ when the steam/biochar ratio kept stationary as 1 . The change in concentrations of $\mathrm{H}_{2}, \mathrm{CO}, \mathrm{CH}_{4}$ and $\mathrm{CO}_{2}$ according to temperature is illustrated in Figure 4.

As seen in Figure 4, gradually increasing of the downdraft gasifier temperature from $600^{\circ} \mathrm{C}$ to $900^{\circ} \mathrm{C}$ increased the mole fraction of $\mathrm{H}_{2}$ and $\mathrm{CO}$ by about $3 \%$ and $2 \%$ respectively while the mole fraction of $\mathrm{CH}_{4}$ and $\mathrm{CO}_{2}$ decreased by about $2 \%$ and $1 \%$. On the other hand, $\mathrm{CO}$ concentration showed decreasing trend the temperature between $600-640^{\circ} \mathrm{C}$ while $\mathrm{CO}_{2}$ concentration depicted slight increase between these temperature. This behavior can be explained with the forward reaction of water-gas shift (Eqn.3). After this point, $\mathrm{CO}$ concentration increased related to endothermic steam-methane reforming (Eqn.2) and Boudouard reactions (Eqn.1) that promoted at higher temperature related to Le Chatelier's principle. The reactions that take place in gasification process are presented as following:

Boudouard Reaction:

$\mathrm{C}+\mathrm{CO}_{2} \leftrightarrow 2 \mathrm{CO}$

Steam Reforming Reaction:

$\mathrm{CH}_{4}+\mathrm{H}_{2} \mathrm{O} \leftrightarrow \mathrm{CO}+3 \mathrm{H}_{2}$

Water - Gas Shift Reaction:

$\mathrm{CO}+\mathrm{H}_{2} \mathrm{O} \leftrightarrow \mathrm{CO}_{2}+\mathrm{H}_{2}$

Increasing temperature promoted the forward reaction of the steam-methane reforming, in this way $\mathrm{H}_{2}$ was produced while the $\mathrm{CH}_{4}$ was consumed. Increasing temperature activated also the solid-char gasification reaction and enhanced the $\mathrm{H}_{2}$ concentration in syngas.

Water - Gas Reaction:

$\mathrm{C}+\mathrm{H}_{2} \mathrm{O} \leftrightarrow \mathrm{CO}+\mathrm{H}_{2}$

As can be understood from the examination of the results, the equilibrium reactions are shifting towards the products with the increase of temperature and produce more $\mathrm{H}_{2}$ and $\mathrm{CO}$.

These changes in the syngas composition affects the syngas quality and accordingly LHV of syngas. The change of syngas LHV was investigated the gasifier

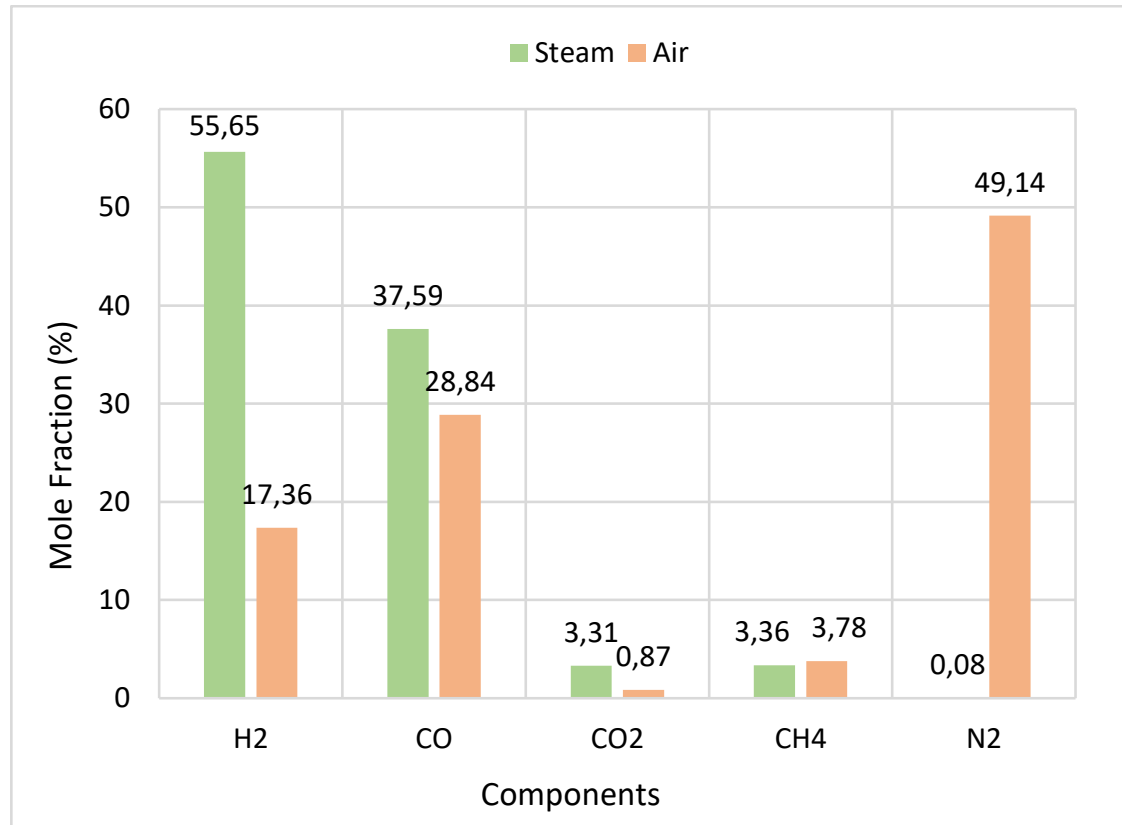

Figure 3. Comparison of the syngas composition under the steam and air atmosphere. 
temperature changing between $600-900^{\circ} \mathrm{C}$ as shown in Figure 5.

The syngas LHV suddenly decreased from 19620 to $19425 \mathrm{~kJ} / \mathrm{kg}$ the temperature between $600-660^{\circ} \mathrm{C}$ after this point LHV value increased and reached its maximum value $19708 \mathrm{~kJ} / \mathrm{kg}$ at the highest temperature. The decrease in LHV at lower temperature can be explained with the rapid and notable decrease in $\mathrm{CH}_{4}$ that is more effective than other gases on the LHV and slight decrease of $\mathrm{CO}$. On the other hand, the decrease in combustible $\mathrm{CH}_{4}$ and $\mathrm{CO}$ concentrations and increase in non-combustible $\mathrm{CO}_{2}$ caused the decrease in syngas LHV.

Enhancing temperature increased the amount of $\mathrm{H}_{2}$ and $\mathrm{CO}$ and decreased the $\mathrm{CO}_{2}$ as mentioned above. Thus, syngas LHV remarkably increased from 19425 $\mathrm{kJ} / \mathrm{kg}$ to $19708 \mathrm{~kJ} / \mathrm{kg}$ with temperature increase. These changes in syngas composition were found compatible with the literature (Ramzan et al., 2011).

\section{Effect of Steam/Biochar Ratio}

The steam/biochar ratio is a very important parameter for $\mathrm{H}_{2}$ production in gasification processes which carried out in the steam atmosphere. The steam/biochar ratio was changed to examine the syngas composition in the range between 0.5 and 1.5. The variation in gas concentrations according to steam/biochar ratio can be seen in Figure 6 .
Increasing in the ratio of steam/biochar resulted an increase in the amount of $\mathrm{H}_{2}$ and $\mathrm{CO}_{2}$ and a decrease in the amount of $\mathrm{CO}$ and $\mathrm{CH}_{4}$. The equilibrium reactions produced more $\mathrm{H}_{2}, \mathrm{CO}_{2}$ and $\mathrm{CO}$ with addition of the steam related to steam reforming (Eqn.2), water-gas shift (Eqn.3) and water-gas (Eqn.4) reactions. $\mathrm{H}_{2}$ concentration continuously increased from $54.5 \%$ to $56.8 \%$ with steam increase, however $\mathrm{CO}_{2}$ concentration reasonably enhanced in the syngas that is the undesirable situation. On the other hand, because the water-gas shift reaction (Eqn.3) was dominant over the other reactions, the decrease was observed in the amount of $\mathrm{CO}$. These changes of CO composition in syngas are compatible with the literature (Tavares et al., 2020).

Considering the effect of steam/biochar ratio on the syngas composition, LHV of syngas that has powerful relationship with the syngas composition was examined using sensitivity analysis for varying steam/biochar ratio. The effect of steam addition on the LHV of syngas is given in Figure 7.

Because of the slight increase in $\mathrm{CO}$ and only small decrease in $\mathrm{CO}_{2}$ caused the little rise in LHV between the steam/biochar ratio 0.5-0.6. Although the $\mathrm{H}_{2}$ concentration increased, the $\mathrm{CO}$ and $\mathrm{CH}_{4}$ concentrations that highly influencial on the LHV due to their combustible properties decreased and LHV of syngas began to decrease with addition of steam after the steam/biochar ratio 0.6 . Thus, it was proved that the $\mathrm{H}_{2}$

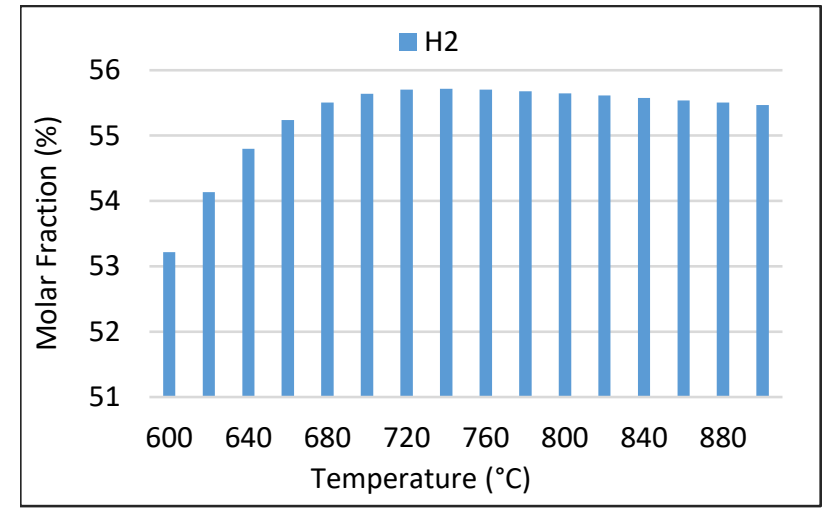

(a)

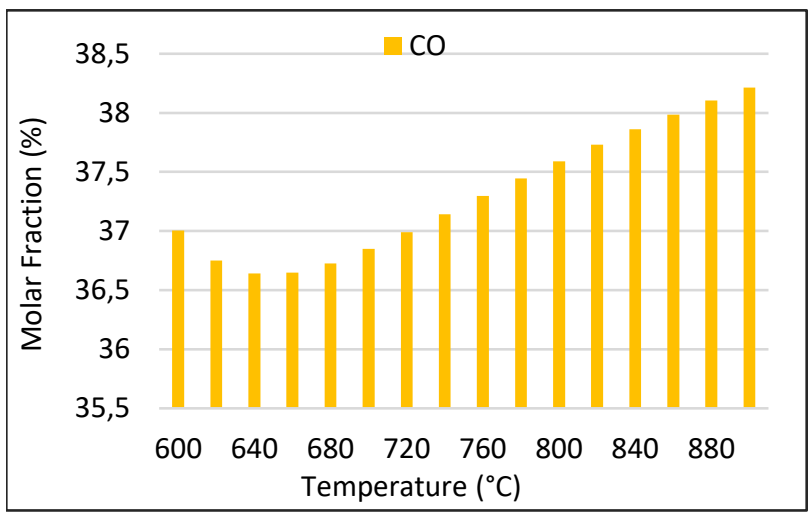

(c)

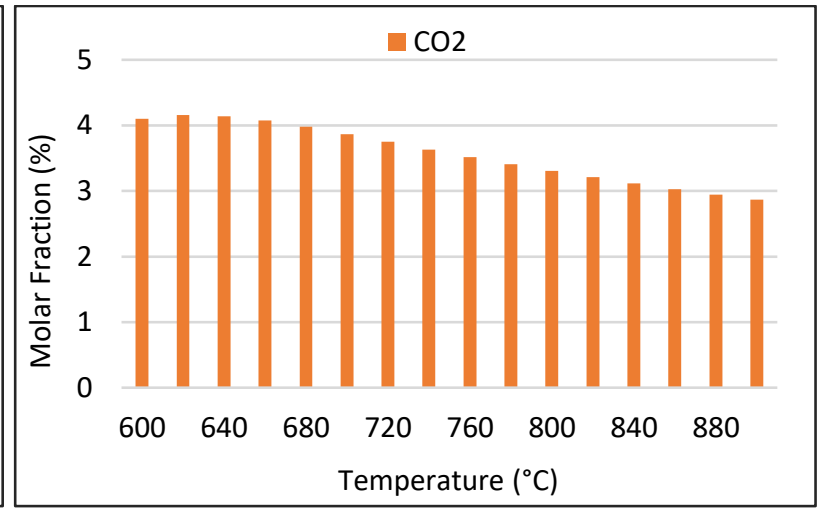

(b)

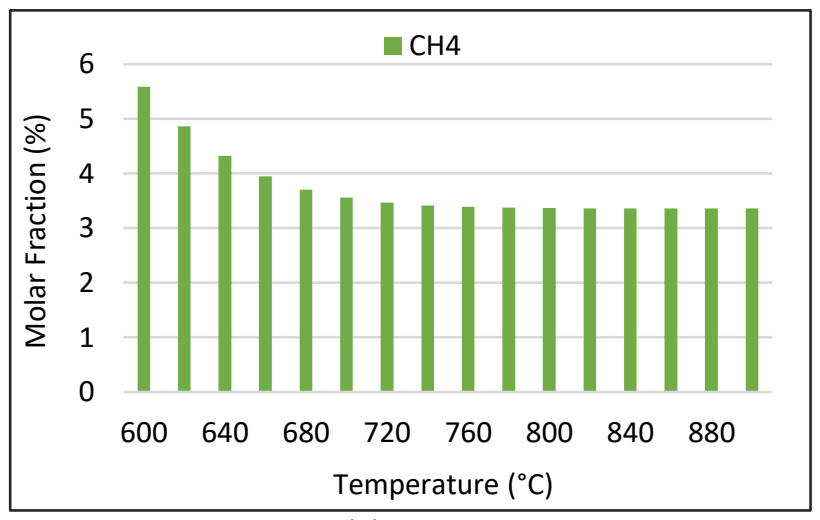

(d)

Figure 4. Temperature effect on syngas composition. (a) $\mathrm{H}_{2}$, (b) $\mathrm{CO}_{2}$, (c) $\mathrm{CO}$, (d) $\mathrm{CH}_{4}$ 


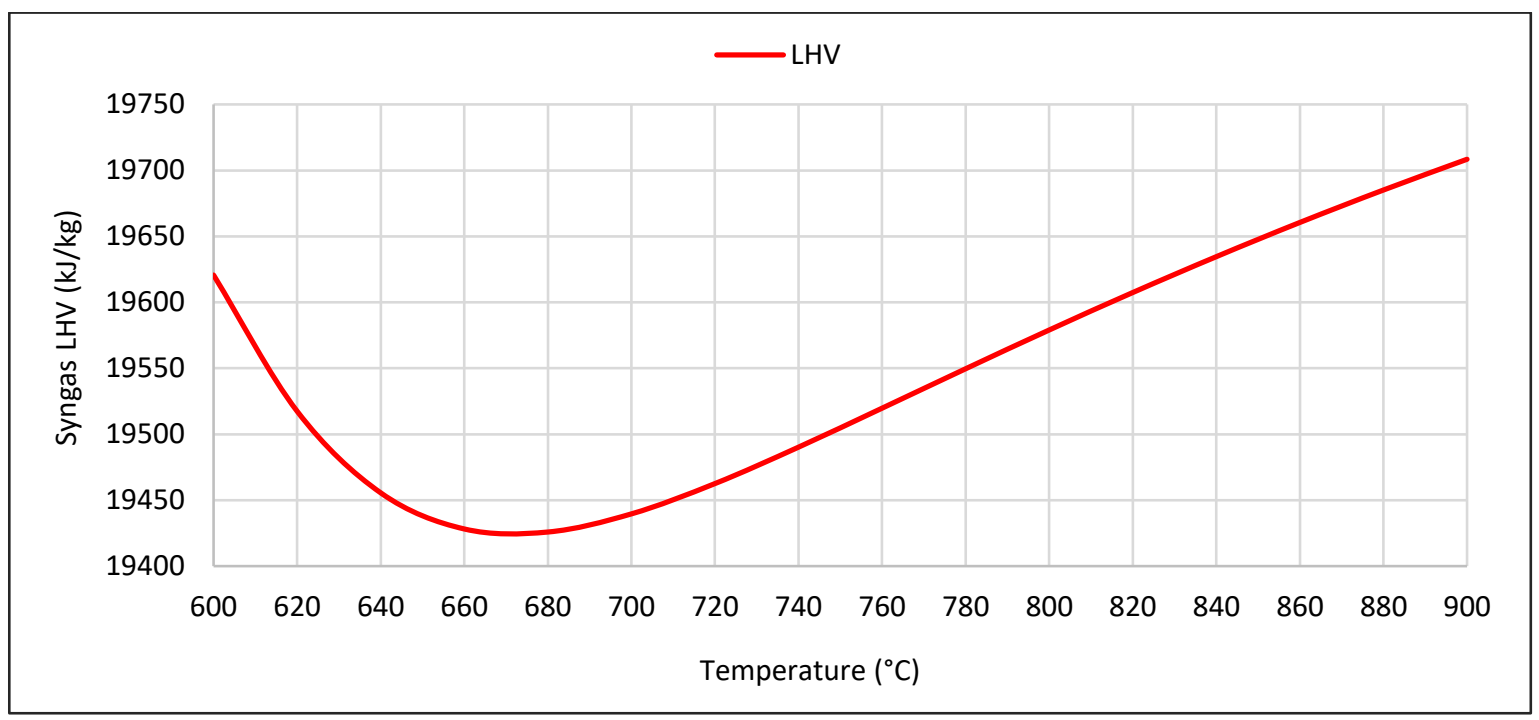

Figure 5. Temperature effect on syngas LHV.

has a rather low effect on LHV of syngas compared to CO and $\mathrm{CH}_{4}$.

\section{Conclusion}

The gasification of biochar in a fixed bed downdraft gasifier was studied using the model developed in Aspen $\mathrm{PLUS}^{\oplus}$ simulation program. The accuracy of the model was proved with the validation studies that conducted with experimental and simulation data taken from the literature. Higher $\mathrm{H}_{2}$ production that aimed in the scope of this work was acquired with the steam gasification.
$0.349 \mathrm{kmol} / \mathrm{h} \mathrm{H}_{2}$ was produced when the steam was preferred as the gasifying agent however only 0.097 $\mathrm{kmol} / \mathrm{h} \mathrm{H}_{2}$ was obtained in the air atmosphere. The LHVand composition of syngas were examined according to gasifier temperature and steam/biochar ratio. Increasing of the downdraft gasifier temperature from $600^{\circ} \mathrm{C}$ to $900^{\circ} \mathrm{C}$ raised the mole fraction of $\mathrm{H}_{2}$ and CO by about $3 \%$ and $2 \%$ respectively. Syngas LHV remarkably increased from $19425 \mathrm{~kJ} / \mathrm{kg}$ to $19708 \mathrm{~kJ} / \mathrm{kg}$ with temperature increase. $\mathrm{H}_{2}$ concentration continuously increased from $54.5 \%$ to $56.8 \%$ with steam addition. Besides syngas composition, LHV of syngas

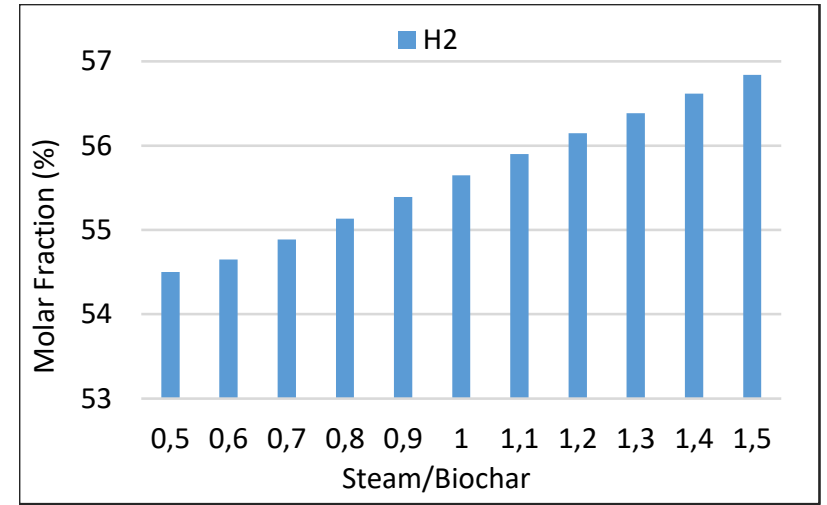

(a)

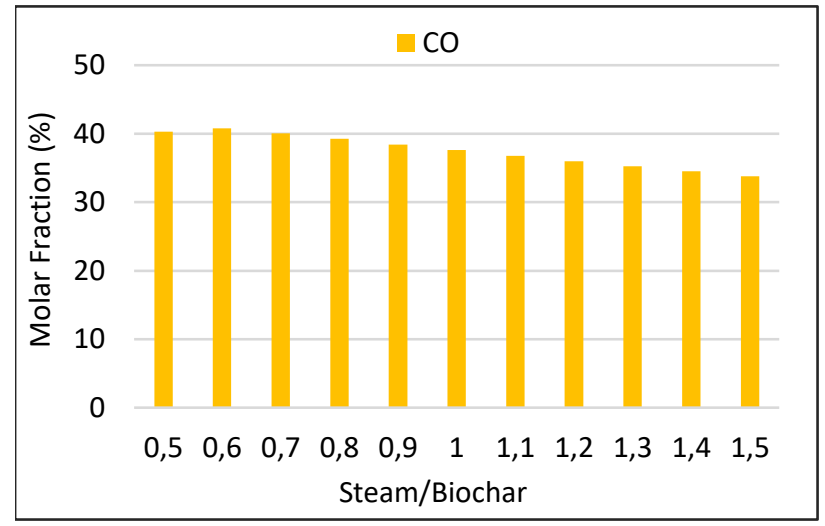

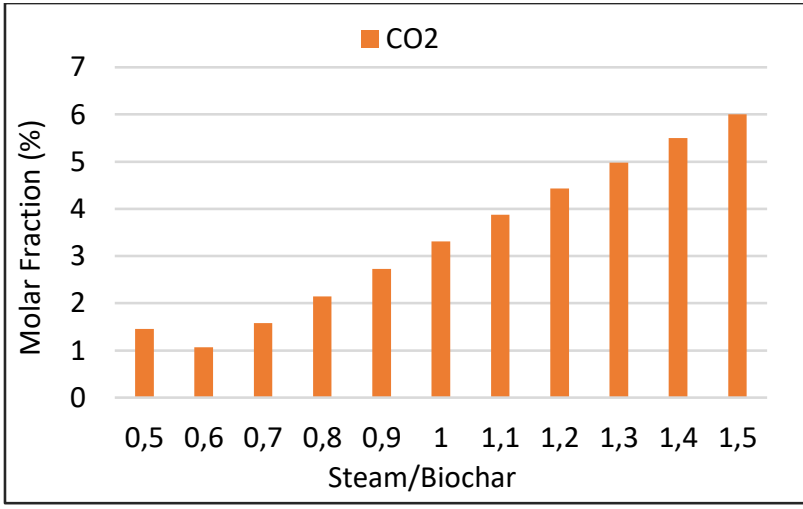

(b)

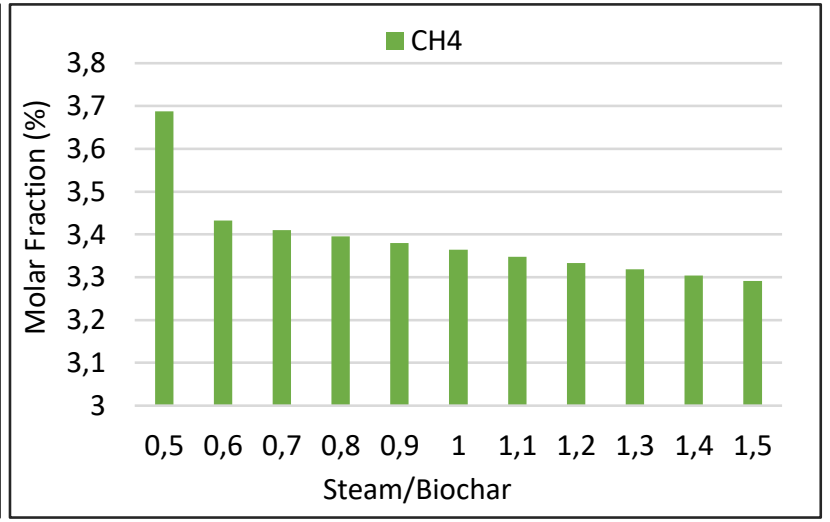

Figure 6. Steam/Biochar effect on syngas composition. (a) $\mathrm{H}_{2}$, (b) $\mathrm{CO}_{2}$, (c) $\mathrm{CO}$, (d) $\mathrm{CH}_{4}$ 


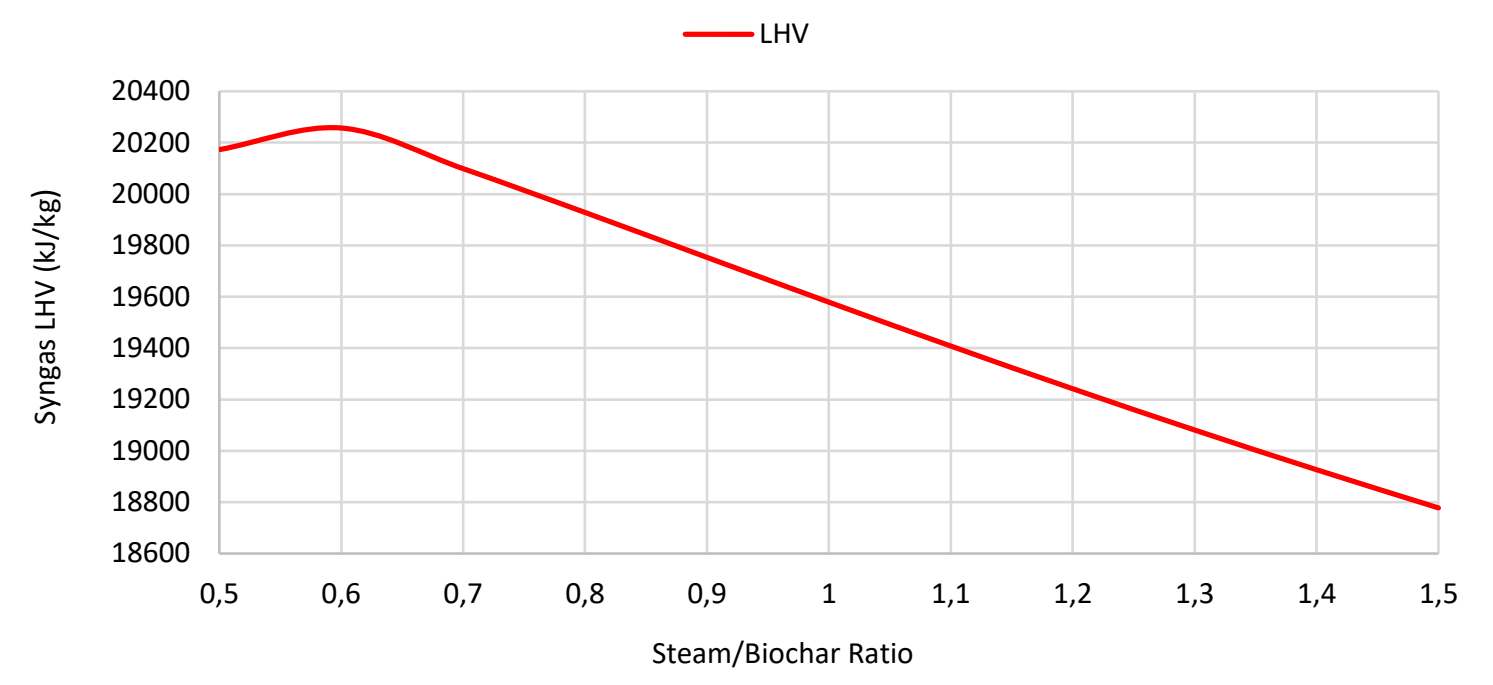

Figure 5. Temperature effect on syngas LHV.

also examined and showed decreasing trend with the increasing of the steam/biochar ratio because of the $\mathrm{CH}_{4}$ and $\mathrm{CO}$ that are the more effective components on the syngas quality. The results obtained from the developed model concluded that the downdraft gasifier model was properly designed for oak wood biochar gasification. The outputs of this study can be good instance for literature and industrial applications.

\section{Conflict of Interest}

The authors declare that they have no known competing financial interests or personal relationships that could have appeared to influence the work reported in this paper.

\section{References}

Baruah, D., \& Baruah, D. (2014). Modeling of biomass gasification: A review. Renewable and Sustainable Energy Reviews, 39, 806-815. https://doi.org/10.1016/j.rser.2014.07.129

Beagle, E., Wang, Y., Bell, D., \& Belmont, E. (2018). Cogasification of pine and oak biochar with sub-bituminous coal in carbon dioxide. Bioresource Technology, 251, 3139. https://doi.org/10.1016/j.biortech.2017.12.027

Cao, L., Iris, K., Xiong, X., Tsang, D. C., Zhang, S., Clark, J. H., Hu, C., Ng, Y. H., Shang, J., \& Ok, Y. S. (2020). Biorenewable hydrogen production through biomass gasification: A review and future prospects. Environmental Research, 186, 109547.

https://doi.org/10.1016/j.envres.2020.109547

Ding, L., Zhang, Y., Wang, Z., Huang, J., \& Fang, Y. (2014). Interaction and its induced inhibiting or synergistic effects during co-gasification of coal char and biomass char. Bioresource Technology, 173, 11-20. https://doi.org/10.1016/j.biortech.2014.09.007

Doherty, W., Reynolds, A., \& Kennedy, D. (2013). Aspen plus simulation of biomass gasification in a steam blown dual fluidised bed. A. Méndez-Vilas (Ed.), Materials and Processes for Energy: Communicating Current Research and Technological Developments (pp. 212-220). Formatex Research Centre
Fernandez-Lopez, M., Pedroche, J., Valverde, J., \& SanchezSilva, L. (2017). Simulation of the gasification of animal wastes in a dual gasifier using Aspen Plus ${ }^{\circledR}$. Energy Conversion and Management, 140, 211-217.

https://doi.org/10.1016/j.enconman.2017.03.008

Guo, F., Dong, Y., Dong, L., \& Guo, C. (2014). Effect of design and operating parameters on the gasification process of biomass in a downdraft fixed bed: An experimental study. International Journal of Hydrogen Energy, 39(11), 5625-5633.

https://doi.org/10.1016/j.ijhydene.2014.01.130

Han, J., Liang, Y., Hu, J., Qin, L., Street, J., Lu, Y., \& Yu, F. (2017). Modeling downdraft biomass gasification process by restricting chemical reaction equilibrium with Aspen Plus. Energy Conversion and Management, 153, 641648. https://doi.org/10.1016/j.enconman.2017.10.030

Hosseini, M., Dincer, I., \& Rosen, M. A. (2012). Steam and air fed biomass gasification: comparisons based on energy and exergy. International Journal of Hydrogen Energy, 37(21), 16446-16452.

https://doi.org/10.1016/j.ijhydene.2012.02.115

Karatas, H., Olgun, H., \& Akgun, F. (2013). Experimental results of gasification of cotton stalk and hazelnut shell in a bubbling fluidized bed gasifier under air and steam atmospheres. Fuel, 112, 494-501. https://doi.org/10.1016/j.fuel.2013.04.025

Menon, S. D., Sampath, K., \& Kaarthik, S. S. (2021). Feasibility studies of coconut shells biomass for downdraft gasification. Materials Today: Proceedings, 44, 31333137.

Patra, T. K., \& Sheth, P. N. (2015). Biomass gasification models for downdraft gasifier: A state-of-the-art review. Renewable and Sustainable Energy Reviews, 50, 583593. https://doi.org/10.1016/j.rser.2015.05.012

Paviet, F., Chazarenc, F., \& Tazerout, M. (2009). Thermo chemical equilibrium modelling of a biomass gasifying process using ASPEN PLUS. International Journal of Chemical Reactor Engineering, 7(1). https://doi.org/10.2202/1542-6580.2089

Rabea, K., Bakry, A. I., Khalil, A., El-Fakharany, M. K., \& Kadous, M. (2021). Real-time performance investigation of a downdraft gasifier fueled by cotton stalks in a batchmode operation. Fuel, 300, 120976. https://doi.org/10.1016/j.fuel.2021.120976 
Ramzan, N., Ashraf, A., Naveed, S., \& Malik, A. (2011). Simulation of hybrid biomass gasification using Aspen plus: A comparative performance analysis for food, municipal solid and poultry waste. Biomass and Bioenergy, 35(9), 3962-3969.

https://doi.org/10.1016/j.biombioe.2011.06.005

Rupesh, S., Muraleedharan, C., \& Arun, P. (2016). ASPEN plus modelling of air-steam gasification of biomass with sorbent enabled $\mathrm{CO} 2$ capture. Resource-Efficient Technologies, 2(2), 94-103. https://doi.org/10.1016/j.reffit.2016.07.002

Safarian, S., Saryazdi, S. M. E., Unnthorsson, R., \& Richter, C. (2020). Artificial neural network integrated with thermodynamic equilibrium modeling of downdraft biomass gasification-power production plant. Energy, 213, 118800.

https://doi.org/10.1016/j.energy.2020.118800

Sezer, S., Kartal, F., \& Özveren, U. (2021). Prediction of chemical exergy of syngas from downdraft gasifier by means of machine learning. Thermal Science and Engineering Progress(25). https://doi.org/https://doi.org/10.1016/j.tsep.2021.10 1031

Sharma, P., Gupta, B., Pandey, M., Bisen, K. S., \& Baredar, P. (2021). Downdraft biomass gasification: A review on concepts, designs analysis, modelling and recent advances. Materials Today: Proceedings, 46, 5333-5341. https://doi.org/10.1016/j.matpr.2020.08.789
Singh, D.K., \& Tirkey, J.V. (2021). Modeling and multi-objective optimization of variable air gasification performance parameters using Syzygium cumini biomass by integrating ASPEN Plus with Response surface methodology (RSM). International Journal of Hydrogen Energy, 46(36), 18816-18831. https://doi.org/10.1016/j.ijhydene.2021.03.054

Spokas, K. A. (2010). Review of the stability of biochar in soils: predictability of O:C molar ratios. Carbon Management, 1(2), 289-303. https://doi.org/10.4155/cmt.10.32

Susastriawan, A., \& Saptoadi, H. (2017). Small-scale downdraft gasifiers for biomass gasification: A review. Renewable and Sustainable Energy Reviews, 76, 989-1003. https://doi.org/10.1016/j.rser.2017.03.112

Tavares, R., Monteiro, E., Tabet, F., \& Rouboa, A. (2020). Numerical investigation of optimum operating conditions for syngas and hydrogen production from biomass gasification using Aspen Plus. Renewable Energy, 146, 1309-1314. https://doi.org/10.1016/j.renene.2019.07.051

Udomsirichakorn, J., \& Salam, P. A. (2014). Review of hydrogen-enriched gas production from steam gasification of biomass: the prospect of CaO-based chemical looping gasification. Renewable and Sustainable Energy Reviews, 30, 565-579. https://doi.org/10.1016/j.rser.2013.10.013 